\section{Entecavir (Baraclude) in patients with chronic hepatitis B virus (HPV) infection}

Edited by AdRes Health Economics \& Outcomes Research
BRIEF

DRUG

PROFILE

Last revision June 2008

\begin{abstract}
INTRODUCTION
Hepatitis $B$ is the most common serious liver infection in the world, with about 350 million people who are infected with the hepatitis $B$ virus (HBV) and about 1 million deaths annually. Hepatitis $B$ is characterized by an acute and a chronic phase, if the subject fails to produce adequate immune response. About 5-10\% of adults infected with HBV go on to develop chronic infection and become chronic carriers (CHB); moreover, the liver damage, if not stopped, continues until cirrhosis or hepatocellular carcinoma. In the natural history of HBV infection, the most important event is $\mathrm{HBeAg}$ seroconversion, characterized by loss of $\mathrm{HBeAg}$ (a specific antigen of the virus) and development of Anti-HBe antibodies (HBeAg-positive patients). If the seroconversion has occurred early (when liver damage is not yet significant) and is maintained, long-term prognosis is excellent. The disease can follow a more aggressive course if active viral replication persists despite anti-HBe positivity. This state, characterized by continuing viral replication, has been termed as $\mathrm{HBeAg}$-negative $\mathrm{CHB}$, and is the most prevalent form in Italy. At the moment, there are 4 approved antiviral drug classes, with different antiviral efficacy, for the treatment of chronic hepatitis B: interferons, nucleoside analogues, nucleotide analogues, and cyclopents. The primary target of the treatment is a prolonged suppression of viral replication, in order to avoid long term complications and increase survival.
\end{abstract}

\section{INDICATIONS AND DOSING}

Entecavir (ETV) is a new active substance, a guanosine analogue with selective activity against HBV, indicated for the treatment of chronic hepatitis $B$ in adults with compensated liver disease, evidence of active viral replication and signs of liver damage. The drug is available in two pharmaceutical forms: film-coated tablets, which contain 0.5 or $1 \mathrm{mg}$ of ETV anhydrous, and oral solution $(0.05 \mathrm{mg} / \mathrm{ml}$ of active substance). Entecavir is taken once daily, with a dose of $0.5 \mathrm{mg}$ for patients never treated with a nucleoside analogue and with a dose of $1 \mathrm{mg}$ in patients refractory to lamivudine (LVD). This drug is currently included by AIFA (Agenzia Italiana del Farmaco) in a drug efficacy and safety monitoring program.

\section{PHARMACOKINETICS}

Pharmacokinetics of ETV is characterized by a moderate inter-individual variability. Coadministration of food reduces Cmax by about $50 \%$ and AUC by $20 \%$, while Tmax is increased; PK/PD modeling showed that in treatment of naïve subjects ETV could be taken with or without food, but in LVD-refractory patients this drug must be taken at least 2 hours before or after meals. Cmax and AUC increased in patients with renal impairment and in elderly subjects; for this population base dose adjustment is required.

\section{PHARMACODYNAMICS}

Entecavir is a cyclopentyl guanine analogue and inhibits selectively HBV polymerase (reverse transcriptase) by competing with the natural substrate deoxyguanosine triphosphate.

\section{EFFICACY AND SAFETY}

Three phase III trials have been conducted to test ETV efficacy and safety: two of them (AI463022 and Al463-027) in nucleoside-naïve subjects, and one (Al463-026) in lamivudine-refractory subjects. The primary objective of these studies was to evaluate the efficacy of ETV versus lamivudine treatment in chronic hepatitis B patients with compensated liver disease. The primary efficacy measure for nucleoside-naïve subjects trials is the proportion of subjects who achieved histological improvement, defined as $\geq 2$ points decrease in the Knodell necroinflammatory score with no worsening of fibrosis compared to baseline. In the Al463-026 study (LVD-refractory subjects) there are two co-primary endpoints, the histologic improvement 


\begin{tabular}{|c|c|c|c|}
\hline \multicolumn{4}{|c|}{ Absorption } \\
\hline Bioavailability & Cmax & Tmax & Binding to plasma proteins \\
\hline $70 \%$ & $\begin{array}{c}4.2 \mathrm{ng} / \mathrm{ml}-8.2 \mathrm{ng} / \mathrm{ml} \\
\text { (for } 0.5 \mathrm{mg} \text { and } 1 \mathrm{mg} \text { dose } \\
\text { respectively) }\end{array}$ & $0.5-1.5 h$ & $13 \%$ \\
\hline \multicolumn{4}{|c|}{ Metabolism and distribution } \\
\hline $\begin{array}{c}\text { Volume of } \\
\text { distribution }\end{array}$ & Metabolism & Metabolites & $\begin{array}{c}\text { Biological activity } \\
\text { of metabolites }\end{array}$ \\
\hline $\begin{array}{l}\text { Vz/F : } 2,550 \text { to } \\
7,708 \text { I }\end{array}$ & $\begin{array}{c}\text { Low metabolism } \\
\text { (metabolites excreted are } \\
<10 \% \text { of administered dose) }\end{array}$ & $\begin{array}{l}\text { Minor amounts of phase } 2 \\
\text { metabolites (glucuronide, } \\
\text { sulfate conjugates) }\end{array}$ & Not present \\
\hline \multicolumn{4}{|c|}{ Elimination } \\
\hline Clearance & Plasma terminal half-life & Elimination & Interactions \\
\hline $400 \mathrm{ml} / \mathrm{min}$ & $130 \mathrm{~h}$ & $76 \%$ urine, $6 \%$ faeces & $\begin{array}{l}\text { Drugs that reduce renal } \\
\text { function or compete for active } \\
\text { tubular secretion }\end{array}$ \\
\hline
\end{tabular}

Table I

Absorption, distribution, metabolism and elimination of entecavir after oral administration

and the composite endpoint, definite as the proportion of subjects with undetectable HBV DNA $(<0.7 \mathrm{mEq} / \mathrm{ml})$ and normalization of serum ALT $(<1.25 \times \mathrm{ULN})$. Subjects are differentiated in $\mathrm{HBeAg}$-positive $(\mathrm{HBeAg}+)$ and $\mathrm{HBeAg}$-negative $(\mathrm{HBeAg-})$ : $\mathrm{HBeAg}$ is a portion of the core antigen of the virus generally released during the infectiveness phase, and its persistence in the serum is associated with active chronic hepatitis. Duration of all main studies was 52 weeks for subjects with complete response (HBV DNA $<0.7 \mathrm{mEq} / \mathrm{ml}$ and $\mathrm{HBeAg}$-) or no response (HBV DNA $>0.7 \mathrm{mEq} / \mathrm{ml}$ ), extended to 92 weeks for partial responders (HBV DNA $<0.7 \mathrm{mEq} / \mathrm{ml}$ and $\mathrm{HBeAg}+$ ).

The statistical histological, biological and virological superiority of ETV compared to LVD was demonstrated at 48 and 24 weeks, and also in patients resistant to LVD. The safety profile of the drug is comparable to the one of LVD, although the question about ETV cancerogenity is still open; animals studies suggest a potential cancerogenic effect for the drug, and clinical follow-up data reported an incidence of 3.5/1,000 cases of hepatocarcinomas in ETV-treated patients.

\begin{tabular}{|c|c|c|c|c|}
\hline Study & Design & Comparator & Efficacy & Safety \\
\hline \multicolumn{5}{|c|}{ Naive subjects } \\
\hline Al463-022 & $\begin{array}{l}1,056 \mathrm{HBeAg}+\text { patients. } \\
\text { Multicenter (137), } \\
\text { randomized } 1: 1 \text {, } \\
\text { double-blind study }\end{array}$ & $\begin{array}{l}\text { ETV } 0.5 \text { mg QD (354 pt) } \\
\text { LVD } 100 \text { mg QD (355 pt) }\end{array}$ & $\begin{array}{l}\text { Histological improvement } \\
(N C=F) \text { : ETV } 72 \% \text { vs LVD } 62 \% . \\
\text { ETV is superior to LVD, } p=0.0085 \\
\text { (NC=M): ETV } 77 \% \text { vs LVD } 72 \% . \\
\text { ETV is non-inferior to LVD, } p=0.191\end{array}$ & $\begin{array}{l}\text { Most common AEs: } \\
\text { headache }(9 \%), \text { fatigue } \\
(6 \%) \text {, dizziness (4\%), and } \\
\text { nausea }(3 \%)\end{array}$ \\
\hline Al463-027 & $\begin{array}{l}\text { 1,468 HBeAg-/antiHBe+ } \\
\text { patients. Multicenter } \\
\text { (146), randomized 1:1, } \\
\text { double-blind study }\end{array}$ & $\begin{array}{l}\text { ETV } 0.5 \text { mg QD (325 pt) } \\
\text { LVD } 100 \text { mg QD (313 pt) }\end{array}$ & $\begin{array}{l}\text { Histological improvement } \\
(\mathrm{NC}=\mathrm{F}) \text { : ETV } 70 \% \text { vs LVD } 61 \% . \\
\text { ETV is superior to LVD, } p=0.0143 \\
\text { (NC=M): ETV } 78 \% \text { vs LVD } 70 \% . \\
\text { ETV is superior to LVD, } p=0.0212\end{array}$ & \\
\hline \multicolumn{5}{|c|}{ LVD-refractory subjects } \\
\hline Al463-026 & $\begin{array}{l}420 \mathrm{HBeAg}+\text { patients. } \\
\text { Multicenter (84), } \\
\text { randomized } 1: 1 \text {, double- } \\
\text { blind study }\end{array}$ & $\begin{array}{l}\text { ETV } 1 \text { mg QD (141 pt) } \\
\text { LVD } 100 \text { mg QD (145 pt) }\end{array}$ & $\begin{array}{l}\text { Histological improvement } \\
(N C=F) \text { : ETV } 55 \% \text { vs LVD } 28 \% . \\
\text { ETV is superior to LVD, } p=<0.001 \\
\text { (NC=M): ETV } 62 \% \text { vs LVD } 33 \% \text {. } \\
\text { ETV is superior to LVD, } p=<0.001 \\
\text { Composite endpoint* } \\
\text { (NC=F): ETV } 55 \% \text { vs LVD } 4 \% . \\
\text { ETV is superior to LVD, } p=<0.001 \\
\text { (NC=M): ETV } 57 \% \text { vs LVD } 4 \% . \\
\text { ETV is superior to LVD, } p=<0.001\end{array}$ & \\
\hline
\end{tabular}

\section{Table II}

Summary of main studies investigating efficacy and safety of entecavir in hepatitis B chronic patients. Subjects with missing data at week 48 can be included $(N C=F)$ or excluded $(N C=M)$ from the analysis

*intended as HBV DNA $<0.7 \mathrm{mEq} / \mathrm{ml}$ and serum ALT $<1.25 \times$ ULN

$\mathrm{AEs}=$ adverse events; ETV = entecavir; LVD = lamivudine; $\mathrm{QD}=$ once daily 


\section{ECONOMIC EVALUATIONS}

Costs of currently approved products for chronic hepatitis B treatment can vary widely: factors affecting costs include the direct cost of the drug, length of treatment, and complication associated with continued therapy, like development of resistance or intolerable adverse events.

Currently there are six approved drugs for the hepatitis B therapy: interferon alpha-2b, pegylated interferon alpha-2a, and four oral monotherapeutic agents (adefovir dipivoxil, entecavir, lamivudine and telbivudine). Injectable interferons and oral drugs represent two different pharmacological approaches, the first based on host immunity stimulation, and the other on a direct antiviral action. Furthermore, polymerase inhibitors need to be indefinitely administered since they are unable to induce a sustained response, even after years of continuous administration. Nevertheless, costs of treatment with oral drugs represent a drastic reduction compared to subcutaneous therapy, and these treatments are also associated with a good response rate and an excellent safety profile, making the overall treatment cost effective. The main limitation of these drugs is the emerging of resistance during the treatment: in particular patients treated with lamivudine, which is effective and not expensive, reported high resistance rates, ranging from $14 \%-32 \%$ after 1 year of therapy to $58 \%$ with $2-3$ years.

\begin{tabular}{|c|c|c|c|c|}
\hline Study & Comparators & Methods & Results & Conclusions \\
\hline $\begin{array}{l}\text { Yuan } \\
\text { et al, } \\
2008 \text { (b) }\end{array}$ & ETV, LVD & $\begin{array}{l}\text { Subjects: } 519 \\
\text { Efficacy end point ( } 48 \text { weeks): pts achieving } \\
\text { HBV DNA }<300 \text { copies/ml } \\
\text { Daily prices assumed: ETV } 40 \text { RMB ( } € 3.64) \text {, } \\
\text { LVD 16.71 RMB ( } € 1.52) \\
\text { Direct medical cost, utility scores: estimated } \\
\text { from published China specific data } \\
\text { 3\% annual discount applied } \\
\text { Time horizon: } 1 \text { year } \\
\text { Setting: China }\end{array}$ & $\begin{array}{l}\text { Efficacy: ETV was superior } \\
\text { to LVD }(78.7 \% \text { vs } 46.7 \% \text {, } \\
p<0.05) \\
\text { ICER: } 17,590 \text { RMB/QALY } \\
\text { gained (about } € 1,600) \text { for } \\
\text { ETV }\end{array}$ & $\begin{array}{l}\text { ETV is cost effective } \\
\text { in treating hepatitis B } \\
\text { pts in China, based } \\
\text { on the World Health } \\
\text { Organization's } \\
\text { recommended maximum } \\
\text { willingness to pay } \\
\text { threshold }\end{array}$ \\
\hline $\begin{array}{l}\text { Veenstra } \\
\text { et al, } \\
2008\end{array}$ & ETV, ADF, LVD; & $\begin{array}{l}\text { Subjects: HBeAg- pts. Addition of ADF or ETV } \\
\text { for LVD-refractary pts } \\
\text { Disease progression probabilities, costs and } \\
\text { quality of life data derived from literature } \\
\text { Evaluated } 5 \text {-year, } 10 \text {-year, lifetime and } 5 \text { on-1 } \\
\text { off treatment durations } \\
\text { Time horizon: lifetime } \\
\text { Setting: USA }\end{array}$ & $\begin{array}{l}\text { All three drugs are cost- } \\
\text { effective } \\
5 \text { on- } 1 \text { off strategy was the } \\
\text { most cost-effective } \\
\text { ICER: } 148,200 \text { \$QALY for } \\
\text { lifetime vs } 5 \text { on-1 off for ETV }\end{array}$ & $\begin{array}{l}\text { In HBeAg- CHB } \\
\text { infection, a } 5 \text { on-1 off } \\
\text { treatment strategy with } \\
\text { ETV is cost-effective } \\
\text { compared to alternative } \\
\text { strategies }\end{array}$ \\
\hline $\begin{array}{l}\text { Yuan } \\
\text { et al, } \\
2008 \text { (a) }\end{array}$ & ETV, LVD & $\begin{array}{l}\text { Subjects: HBeAg+ pts } \\
\text { Efficacy end point ( } 48 \text { weeks): pts achieving } \\
\text { HBV DNA }<300 \text { copies/ml } \\
\text { Annual prices assumed: ETV } \$ 7,365 \text {, } \\
\text { LVD } \$ 2,604 \\
\text { Efficacy and safety data from clinical trials, } \\
\text { other model parameters from literature } \\
\text { 3\% annual discount applied } \\
\text { Time horizon: } 10 \text { years } \\
\text { Setting: USA }\end{array}$ & $\begin{array}{l}\text { Efficacy: ETV superior to LVD } \\
(69.1 \% \text { vs } 39.8 \%, p<0.001) \\
\text { ICER: } 3,230 \$ / \text { QLY gained } \\
\text { for ETV }\end{array}$ & $\begin{array}{l}\text { ETV given for up to } 10 \\
\text { years would be highly } \\
\text { cost-effective in } \\
\text { HBeAg+ pts }\end{array}$ \\
\hline $\begin{array}{l}\text { Veenstra } \\
\text { et al, } \\
2007\end{array}$ & ETV, LVD & $\begin{array}{l}\text { Subjects: } 709 \mathrm{HBeAg}+\text { pts. Addition of ADF } \\
\text { for LVD-refractary pts } \\
\text { Clinical and economic inputs from publicly } \\
\text { available data } \\
\text { Analysis performed by a Markov model } \\
\text { Time horizon: lifetime } \\
\text { Setting: USA }\end{array}$ & $\begin{array}{l}\text { Estimated 10-year } \\
\text { cumulative incidence of } \\
\text { cirrhosis: ETV } 20.5 \% \text {, } \\
\text { LVD 22.8\% } \\
\text { ICER: } 7,600 \text { \$/QALY }\end{array}$ & $\begin{array}{l}\text { ETV is cost-effective } \\
\text { compared with LVD } \\
\text { with ADF salvage or } \\
\text { combination therapy }\end{array}$ \\
\hline $\begin{array}{l}\text { Kanwal } \\
\text { et al, } \\
2005\end{array}$ & ETV, ADF, LVD & $\begin{array}{l}\text { Subjects: HBV pts with cirrhosis } \\
\text { The study evaluated the cost-effectiveness of } \\
\text { six strategies: } \\
\text { (1) No HBV treatment ("do nothing") } \\
\text { (2) LVD monotherapy } \\
\text { (3) ADF monotherapy } \\
\text { (4) LVD with crossover to ADF on resistance } \\
\text { ("ADF salvage") } \\
\text { (5) ETV monotherapy } \\
\text { (6) LVD with crossover to ETV on resistance } \\
\text { ("ETV salvage") }\end{array}$ & $\begin{array}{l}\text { (1) least effective yet least } \\
\text { expensive } \\
\text { (3) vs (1) incremental cost of } \\
\$ 19,731 \\
\text { (5) vs (3) more effective yet } \\
\text { more expensive, incremental } \\
\text { cost 25,626 \$/QALY } \\
\text { (2), (4) and (6) not cost- } \\
\text { effective } \\
\text { (4) vs (6) more effective and } \\
\text { less expensive }\end{array}$ & $\begin{array}{l}\text { Both ETV and ADF are } \\
\text { cost-effective in pts with } \\
\text { HBV cirrhosis; choosing } \\
\text { between ADF and ETV } \\
\text { is highly dependent on } \\
\text { available budgets. In } \\
\text { pts who developed LVD } \\
\text { resistance, "ADF salvage" } \\
\text { appears more effective } \\
\text { and less expensive than } \\
\text { "ETV salvage" }\end{array}$ \\
\hline
\end{tabular}

\section{Table III}

Economic evaluations of the cost-effectivness of entecavir in the therapy of chronic hepatitis $B$

ADF = adefovir; ETV = entecavir; LVD = lamivudine; pts = patients; RMB = renminbi, currency of the People's Republic of China 


\begin{tabular}{|c|c|c|c|c|c|c|c|}
\hline & RS & & Frequency & Package & Price & $\begin{array}{l}\text { Ex-factory } \\
\text { price }\end{array}$ & $\begin{array}{l}\text { Monthly } \\
\text { price*** }\end{array}$ \\
\hline \multicolumn{8}{|l|}{ Self-injectable drugs } \\
\hline Interferon alpha-2b (HBeAg + pts) & PHT & $10 \mathrm{MUI}$ & 3 times a week & 1 vial & 88.46 & 53.60 & 611.03 \\
\hline Interferon alpha-2b (HBeAg + pts) & PHT & $18 \mathrm{MUI}$ & 3 times a week & 1 vial & 147.46 & 89.35 & 565.87 \\
\hline Interferon alpha-2b (HBeAg + pts) & PHT & $25 \mathrm{MUI}$ & 3 times a week & 1 vial & 203.69 & 123.42 & 562.78 \\
\hline Interferon alpha-2b (HBeAg- pts) & PHT & $10 \mathrm{MUI}$ & 4 times a week & 1 vial & 88.46 & 88.46 & 353.75 \\
\hline Interferon alpha-2b (HBeAg- pts) & $\mathrm{PHT}$ & $18 \mathrm{MUI}$ & 5 times a week & 1 vial & 147.46 & 147.46 & 327.61 \\
\hline Interferon alpha-2b (HBeAg- pts) & PHT & $25 \mathrm{MUI}$ & 6 times a week & 1 vial & 203.69 & 203.69 & 325.82 \\
\hline Peginterferon alpha-2a* & PHT & $180 \mathrm{mcg}$ & 3 times a week & 1 vial & 321.41 & 194.75 & 778.98 \\
\hline \multicolumn{8}{|l|}{ Oral drugs } \\
\hline Adefovir dipivoxil* & $\mathrm{H}$ & $10 \mathrm{mg}$ & Daily & 30 tablets & 705.55 & 427.50 & 399.00 \\
\hline Entecavir* & $\mathrm{H}$ & $0.5 \mathrm{mg}$ & Daily & 30 tablets & 670.28 & 406.13 & 379.05 \\
\hline Entecavir* & $\mathrm{H}$ & $1 \mathrm{mg}$ & Daily & 30 tablets & 670.28 & 406.13 & 379.05 \\
\hline Lamivudine & PHT & $100 \mathrm{mg}$ & Daily & 28 tablets & 89.57 & 54.27 & 54.27 \\
\hline Lamivudine & PHT & $5 \mathrm{mg}$ & Daily & Oral solution (240 ml) & 38.43 & 23.29 & 54.33 \\
\hline Telbivudine* & $\mathrm{H}$ & $600 \mathrm{mg}$ & Daily & 28 tablets & 625.58 & 379.04 & 379.04 \\
\hline
\end{tabular}

Table IV

Monthly pharmaceutical costs of different available therapies for chronic hepatitis B treatments

*Price neglects further negotiated discounts on supplies for NHS

** Four weeks

$\mathrm{H}=$ hospital prontuary; $\mathrm{PHT}=$ hospital-territorial prontuary; pts = patients; $\mathrm{RS}$ = reimbursement status

In Table III we reviewed the main economic evaluations we found in PubMED for ETV. Generally this drug appears to be cost-effective in chronic hepatitis B therapy, particularly if compared to LVD. LVD, the first oral nucleoside analog approved for the treatment of CHB, presents a lower acquisition cost ( $\$ 4,671$ less per patient per year respect to ETV), but patients treated with this drug reported high resistence rates (14-32\% vs $0 \%$ of ETV); both adefovir and ETV present lower viral resistance rates, but are more expensive. The cost-effectiveness of ETV compared with adefovir for nucleos(t)ide treatment-naïve patients is in need of investigation. In Table IV we calculated the monthly pharmaceutical cost in Italy of available hepatitis B treatment: this is not to be intended as a cost-minimization analysis, but as a simple overlook of currently available treatments. Considered dosages are those derived from reference trials or from the SPCs of the products. For interferon alpha-2b, we considered a dosing of 9-10 $\mathrm{MUI} / 3$ times a week for $\mathrm{HBeAg}+$ patients and of 5-6 MUI/3 times a week for HBeAg-, as seen in a national treatment protocol. Prices of the drugs are derived from Informatore Farmaceutico 2008: we always considered ex-factory price.

Globally, the monthly cost of telbivudine is nearly the same of entecavir (€ 379), and similar to the one of adefovir; the cost of peginterferon is almost twice, and the less costly drug results lamivudine, with a monthly cost of about $€ 54$.

Name of the Medicinal Product

Marketing Authorisation Holder

Active Substance

Pharmaco-therapeutic Group

ATC Code

Date of issue of Marketing Authorisation valid throughout the European Union
Baraclude

Bristol-Myers Squibb Pharma EEIG

Entecavir

Nucleoside and nucleotide reverse transcriptase inhibitors

J05FA10

26 June 2006 


\section{REFERENCES}

- AIFA - Agenzia Italiana del Farmaco - Elenco dei farmaci sottoposti a monitoraggio intensivo. Available on http://www.agenziafarmaco.it/REGISTRAZIONE_FARMACO/ registrazione_farmaco067.html

- Amarapurkar DN. Telbivudine: a new treatment for chronic hepatitis B. World J Gastroenterol 2007; 13: 6150-5

- Baraclude - EPAR summary for the public

- Baraclude official FDA information, side effects and uses - Professional information. Available on http://www.drugs.com/ppa/entecavir.html

- Baraclude Scientific Discussion - European Medicines Agency (EMEA), 2006. Available on http://www.emea.europa.eu/humandocs/PDFs/EPAR/baraclude/H-623-en6.pdf

- Chang TT, Gish RG, de Man R, Gadano A, Sollano J, Chao YC, et al. A comparison of entecavir and lamivudine for HBeAg-positive chronic hepatitis B. N Engl J Med 2006; 354: $1001-10$

- Gazzetta Ufficiale della Repubblica Italiana - GU 135 - 13/06/2003

- Gazzetta Ufficiale della Repubblica Italiana - GU 271 - 21/11/2007

- Gazzetta Ufficiale della Repubblica Italiana - GU 278 - 26/11/2003

- Gazzetta Ufficiale della Repubblica Italiana - GU 28 - 03/02/2007

- Holbrook ML. Cost-effective pharmacologic therapies to treat chronic hepatitis B: how far have we really come? J Manag Care Pharm 2008; 14: 65-9

- Informatore Farmaceutico 2008, Ed. Elsevier Masson, updated to June, 2008

- Kanwal F, Gralnek IM, Martin P, Dulai GS, Farid M, Spiegel BM. Treatment alternatives for chronic hepatitis B virus infection: a cost-effectiveness analysis. Ann Intern Med 2005; 142: 821-31

- Lai CL, Shouval D, Lok AS, Chang TT, Cheinquer H, Goodman Z, et al. Entecavir versus lamivudine for patients with HBeAg-negative chronic hepatitis B. N Engl J Med 2006; 354: $1011-20$

- Massari M. Protocollo per il trattamento delle epatiti croniche CCV, HBV, HDV. UO Malattie Infettive, ASMN di Reggio Emilia. Reviewed December 2004

- Prescrivere News - Nuove entità terapeutiche. Entecavir: ruolo incerto. Dialogo sui farmaci 2007; 3

- Sherman M, Yurdaydin C, Sollano J, Silva M, Liaw YF, Cianciara J, et al. Entecavir for treatment of lamivudine-refractory, HBeAg-positive chronic hepatitis B. Gastroenterology 2006; 130: 2039-49

- Smith VE, Bruno CJ. The search for cost-effective treatment of chronic hepatitis B. J Manag Care Phar 2008; 14: 61-4

- Veenstra DL, Spackman DE, Bisceglie A, Kowdley KV, Gish RG. Evaluating anti-viral drug selection and treatment duration in HBeAg-negative chronic hepatitis B: a costeffectiveness analysis. Aliment Pharmacol Ther 2008; 27: 1240-52

- Veenstra DL, Sullivan SD, Clarke L, lloeje UH, Tafesse E, Di Bisceglie A, et al. Cost effectiveness of entecavir versus lamivudine with adefovir salvage in $\mathrm{HBeAg}$-positive chronic hepatitis B. Pharmacoeconomics 2007; 25: 963-77

- Yuan Y, Iloeje UH, Hay J, Saab S (a). Evaluation of the cost-effectiveness of entecavir versus lamivudine in hepatitis BeAg-positive chronic hepatitis B patients. J Manag Care Pharm 2008; 14: 21-33

- Yuan Y, lloeje UH, Li H, Hay J, Yao GB (b). Economic implications of entecavir treatment in suppressing viral replication in chronic hepatitis $B(\mathrm{CHB})$ patients in China from a perspective of the Chinese Social Security program. Value Health 2008; 11: S11-22 